\title{
MEMBANGUN KEBENARAN TENTATIF DALAM DISIPLIN AKUNTANSI (TAFSIR DAN KRITIK ATAS KUASA RELATIVITAS KEBENARAN)
}

\author{
Agung Budi Sulistiyo \\ Jurusan Akuntansi Universitas Jember \\ Email: agungbudisulistiyo@gmail.com/Telephon 081336129425
}

\begin{abstract}
This paper attempts to explain that there is the power of relativity of truth in developing the "current" knowledge, no exception in accounting discipline. The context of "current" cannot be separated from the element of time and space where we interact in it. The result of social interaction and the capture of phenomenas is what underlies this paper. The concept of the relativity of thruth to be an axiom that should not be interfered with so that when anyone whom disputed it will be considered intorelant, selfish and small-minded. If we explore this concept in depth, actually the concept will bring us to the paradoxical attitude (double-standard of attitude) and ambivalent (double-standard of truth) in every process of our thought.
\end{abstract}

Keywords: relativity of truth, paradoxical, ambivalent.

\begin{abstract}
Akuntansi "Mana-mana Jo"
Dua orang mahasiswa program doktor tampak serius bersitegang dan berdebat dengan hebat diselingi nada yang meninggi dan wajah yang menegang. Tak jarang keduanya saling memukulkan tangan kanan dan kirinya secara bergantian ke meja kayu yang nampak pasrah dijadikan korbannya. Air peluh mulai bercucuran menandakan luapan emosi yang mulai tak terbendung. Berikut petikan debat diantara mereka:
\end{abstract}

Si A : Pokoknya...yang namanya akuntansi ya harus ada laporan keuangannya, ada jurnalnya, jelas mana aset dan berapa ruginya. Ndak bisa!!kalo sama sekali gak ada muatan itu..itu namanya bukan akuntansi. Jadi..ya jangan ngawur kalo bikin definisi akuntansi..

Si B : Eit..ente kalo ngomong yang ilmiah donk..sekarang jaman sudah berubah..Ente kalo berpikir harus terbuka. Lupa kalo Prof. Don Juan pernah ngomong.."sepanjang masih bicara angka, kita bolehlah menyebut itu akuntansi, why not! Kenapa anda harus takut mengakui hal itu. Anda bisa temukan akuntansi itu di sawah, pegunungan, pasar, supermarket bahkan mall sekalipun. Atau di tempat ibadah, di rumah 
dan boleh jadi you temukan itu di situs purbakala."...Hhmmm..ente jgn terlalu naif berpikir akuntansi sesempit itu...

Dari kejauhan tampak si $\mathrm{C}$ datang berupaya menengahi perdebatan antara si $\mathrm{A}$ dan si B.

Si C : Eh mas berdua..sabar sadiki doe(bersabar sedikit)..tak usah susahsusah bertengkar. Kita ini kan multi paradigma. Kebenaran itu relatif. Janganlah mengklaim diri merasa paling benar. Mana-mana jo..apa ngoni mo suka bilang, kiapa dibekeng repot (terserah mau bilang apa, kenapa dibuat repot)

Itulah sekelumit pembicaraan yang bersifat informal namun mengandung pesan ilmiah yang mendalam. Ada pemikiran yang terkesan jumud, baku, kaku dan sedikit arogan yang mewarnai cara berpikir si A. Berpikir terbuka, up to date, dan fleksibel, boleh jadi itulah representasi dari si B. Dan si C hadir dengan nuansa yang lebih bersahabat dan berupaya merangkul keduanya ibarat seorang ibu yang memiliki dua anak dengan watak yang berbeda namun tetap mencurahkan kasih sayangnya dalam persamaan dan kebersamaan.

Jika kita berbicara akuntansi, sebagian orang akan mengatakan susah dan "njlimet". Begitu pula ketika saya berdiskusi santai dengan seorang teman, ia pun mengatakan akuntansi kan matematikanya ilmu sosial. Dalam hati saya tertawa membayangkan seandainya kalau saya memberitahu dia bahwa dulu akuntansi juga dianggap sebagai bagian dari seni. Yang bener akuntansi itu seni atau matematikanya ilmu sosial. Whatever lah..kenapa kita harus bertengkar masalah julukan? Shakespeare juga berani mengklaim "apalah arti sebuah nama?" Jadi mana-mana jo...

Mendefinisikan akuntansi tentu lebih sulit dibanding sekedar memberikan julukan. Di tahun 1996 saat saya pertama kali menjadi mahasiswa S1 Akuntansi maka kalimat pertama yang saya dengar, lihat dan catat bahwa akuntansi adalah "sebuah proses mencatat, meringkas, dan melaporkan transaksi-transaksi keuangan menjadi sebuah laporan keuangan". Definisi yang terus saya pertahankan hingga di tahun 2010 ketika saya memahami ternyata definisi akuntansi sudah jauh berubah tergantung dari sudut pandang mana kita melihatnya. Akuntansi dari sudut pandang agama tentu akan berbeda jika dilihat menggunakan perspektif budaya, politik atau ekonomi sekalipun. Banyak definisi tergantung seberapa banyak sudut pandang yang digunakan. Different eyes has 
different perspective. Terus yang mau kita pakai yang mana? Kembali orang bijak berkata "Sudahlah napa dibuat repot? Biarkan orang mendefinisikan semaunya, kenapa kamu yang susah? Anything goes ? so..mana-mana jo..

Membicarakan perihal sudut pandang maka para ilmuwan cenderung menyukai istilah paradigma untuk menegaskan hal yang kurang lebih sama maknanya. Dalam konteks akuntansi, para akuntan menggunakan model paradigma sosialnya Burrel dan Morgan (1979), yang kemudian diinterpretasikan ulang oleh Chua (1986) dan Sarantakos (1993) untuk menggambarkan wilayahwilayah risetnya. Pada akhirnya kita mengenal empat paradigma riset akuntansi yakni paradigma positivistik, interpretif, kritis dan posmodernis. Terkait dengan hal tersebut saya teringat seorang guru yang bijak memberitahu :

"Wahai tuan-tuan dan puan-puan..kalau kalian ingin melihat fenomena akuntansi sebatas to explain dan to predict maka gunakanlah cara berpikir positif. Tapi..kalau kalian ingin lebih dari itu, semisal memahami sebuah fenomena atau verstehen maka you pake interpretif. Boleh jadi kalian ingin lebih jauh lagi mencoba untuk mengkritik fenomena yang ada maka kalian berada pada ranah kritis. Akhirnya kalo kalian mampu menghasilkan sesuatu yang baru, bukan hanya sebatas mengkritik, jadilah riset kalian bernuansa posmodern."

Sekilas nampak mudah untuk memahami penjelasan sang guru. Walaupun saya sadar melakukan sebuah riset ilmiah tidak segampang yang dibayangkan. Empat paradigma riset yang digambarkan seolah-olah memiliki batasan (wilayah demarkasi) yang jelas. Tidak ada overlapping di dalamnya. Namun pemahaman saya berubah ketika membaca sebuah artikel yang ditulis oleh Gummesson (2003) yang berjudul "All Research is Interpretive". Hal ini berarti semua paradigma riset yang saya ketahui pada dasarnya berujung pada penafsiran atau pemaknaan atas sebuah fenomena. Seolah-olah paradigma interpretif menjadi pokok bagi semua paradigma. Dengan kata lain garis demarkasi menjadi kabur bahkan hilang sama sekali. Terlebih ketika saya menghadiri beberapa seminar penelitian, ternyata banyak yang melakukan kombinasi paradigma misalnya etnografi kritis atau fenomenologi kritis, yang memperlihatkan adanya perkawinan antar paradigma meskipun masing-masing memiliki perbedaan asumsi. Pernah saya menanyakan kondisi ini kepada seorang guru yang bijak. 
Beliau berkata, "Sudahlah mas, ndak usah terlalu dipikir masalah itu, yang penting kamu bisa menemukan fokus risetmu dan kamu tahu pisau analisis apa yang mau digunakan. Perkara kamu ada di paradigma mana, biarlah orang lain yang menilai..gitu aja kok repot!! Dalam kesunyian saya merenung dan kembali hati kecil saya berkata, "mana-mana jo.."

Membatasi sudut pandang atau paradigma bagi seorang akademisi atau ilmuwan akuntansi bukanlah hal yang bijak untuk dilakukan. Saya teringat kembali sebuah percakapan pendek dengan Prof. Arjuna dalam sebuah diskusi, (Sulistiyo, 2011b). Sebelumnya beliau menegaskan pentingnya mempelajari semua paradigma dan merasakan keunikan yang ada. Merasakan berarti kita ikut terlibat dalam paradigma tersebut dan mengimplementasikannya bukan sekedar mengamati dari luar sebatas memahami metodologinya saja. Ibarat kita mau belajar berenang maka tidak mungkin sebatas kita belajar teori berenang melainkan kita harus masuk ke kolam air atau sungai untuk merasakan sensasinya. Berikut petikan diskusinya.

Saya : "Apakah suatu masalah yang sama bisa dipecahkan dengan menggunakan berbagai paradigma tersebut, prof?"

Profesor: "Ya bisa juga. Hal itu tergantung dari kedalaman dan pola khas dari tiap paradigma. Misalkan pada kasus praktik etika di kantor akuntan publik. Kalau positif kita sudah tahu bersama, adapun dengan interpretif anda sebatas memahami fenomena tersebut. Jika anda melakukan kritik terhadap pola etika standar yang ada maka itu ranahnya kritis. Adapun upaya untuk mendekonstruksi dan memasukkan value baru ke dalam standar etika yang berlaku maka paradigma posmo-lah yang anda gunakan".

Saya : "Lanjut prof..mungkinkah kita menggabungkan semua paradigma tersebut untuk melihat suatu fenomena sehingga kita dapat menangkap realitasnya secara utuh?"

Profesor: "Hhmm...seorang manusia tidaklah mungkin mengungkap realitas di luar dirinya secara utuh. Manusia memiliki keterbatasan akal dan panca indera untuk menangkap maupun menginterpretasikan sebuah fenomena. Dalam pandangan saya berpikir secara multiparadigma bukanlah menggabungkan atau mencampuradukkan semua 
paradigma melainkan anda mampu menguasai semua paradigma tersebut dan menerapkannya sesuai dengan tujuan riset yang ingin anda lakukan.

(sejenak Profesor terdiam dan kemudian mengambil gelas aqua dan meminumnya..). "Dengan kata lain..seorang yang multi memiliki pandangan seperti burung (bird eyes) yang dapat melihat mangsanya (target) dari segala sudut pandang untuk kemudian menangkapnya dengan posisi (sudut pandang) yang tertentu. Janganlah kita memandang seperti seorang pejalan kaki (pedestrian eyes) yang berjalan dengan fokus pada satu sudut pandang saja".

Ada kegamangan dalam diri saya mencoba memahami realitas percampuran atau kombinasi paradigma dan pernyataan Prof. Arjuna yang menganalogikan paradigma sebagai pandangan burung (bird eyes). Boleh jadi secara teknis percampuran paradigma dimungkinkan atau secara teori sebenarnya mustahil untuk dilakukan. Mana yang benar ? dari kejauhan terdengar suara merdu berkata, "masing-masing benar kok mas..suka-sukalah alias mana-mana jo.."

Beberapa dialog yang saya paparkan sebelumnya menyiratkan sebuah prakonsepsi adanya kebebasan dalam menilai segala sesuatu. Ada kenisbian di dalamnya dan ada kerelativan yang melingkupinya. Kerelativan atas hal apa? dalam hal kebenaran tentunya. Sebuah kata dalam diskursus filsafati yang tidak pernah jemu selalu kita perbincangkan yakni relativitas kebenaran.

Relativitas kebenaran dianggap kata kunci untuk membangun semangat kebersamaan, saling menghargai perbedaan dan menciptakan budaya toleran dalam setiap aspek kehidupan. Tiap orang memiliki pikiran, ide dan pendapat yang sangat mungkin bertentangan dengan orang lain. Cukuplah menganggap anda benar, saya juga benar, jadi kita sama-sama benar, menjadi jalan untuk menyelesaikan segala persoalan dalam hidup ini. Oleh karena itu klaim kebenaran menjadi umum dimiliki oleh setiap orang walaupun bersifat kontradiktif satu sama lain. Selanjutnya, penting untuk dikaji lebih jauh asal-usul dan bagaimana konsep relativitas kebenaran itu muncul dan mewujud dalam logika berpikir kita. 


\section{Relativitas Kebenaran: Sebuah Konsep yang Membebaskan atau Membiarkan Berjalan Tanpa Arah?}

Menjadi penting untuk sebelumnya memahami bagaimana dinamika pemikiran para kaum pemikir (filsuf) dalam upayanya mengetahui apa itu sebuah kebenaran. Secara dikotomis kita memahami tipe-tipe kebenaran yang sering diperdebatkan oleh beberapa pihak. Ada kebenaran absolut vs kebenaran relatif, kebenaran tunggal vs majemuk ataupun kebenaran hakiki vs kebenaran semu. Bahkan yang jauh lebih ekstrem jika menganggap tidak ada kebenaran sama sekali dalam semua aspek kehidupan ini.

Dalam peradaban Yunani kuno sekitar abad ke-4 SM dikenal suatu kaum bernama kaum sofis. Kaum sofis adalah sekelompok orang yang dianggap memiliki banyak pengetahuan tentang bahasa, filsafat, politik dan pengetahuan yang lain. Oleh karena itu mereka juga dianggap sebagai orang-orang yang bijaksana dan berpengetahuan (Mujahid 2011, 60). Diantaranya kita mengenal Thales, Pythagoras, Protagoras dan Gorgias.

Filsafat yang dikembangkan kaum sofis adalah mengajarkan bahwa manusia tidak dapat mengetahui apalagi menyingkap hakikat alam semesta ini, bagaimanapun teori-teori yang dapat diajukan. Daripada menyibukkan diri dengan perkara-perkara yang mustahil, seseorang lebih baik memusatkan perhatian kepada permasalahan dirinya (Mujahid 2011, 61). Protagoras menyatakan bahwa manusia adalah ukuran segala sesuatu sehingga manusialah yang dapat menentukan baik dan buruknya segala sesuatu. Dengan kata lain manusia memiliki otoritas untuk menentukan kebenaran bagi dirinya sendiri. Hal ini juga berimplikasi ketika manusia dapat menentukan kebenarannya masingmasing maka di dunia ini tidak ada kebenaran yang mutlak sehingga bagi Protagoras, kebenaran bersifat relatif (Mujahid 2011, 61).

Ada tulisan bagus dari ilmuwan muslim bernama Syamsuddin Arif yang menjelaskan lebih lanjut pemahaman relativitas kebenaran ini dan sekaligus melakukan kritik yang obyektif terhadap konsep tersebut. Pengidap kanker epistemologis untuk kelompok pemikir yang mempertanyakan filosofis kebenaran dan membaginya dalam tiga kategori:

Pengidap kanker epistemologis biasanya memperlihatkan gejala-gejala sebagai berikut. Pertama, bersikap skeptis terhadap segala hal, dari soal sepele hingga masalah-masalah prinsipil dalam agama. la senantiasa meragukan 
kebenaran dan membenarkan keraguan. Baginya, semua pendapat tentang semua perkara (termasuk yang qath'l dan bayyin dalam agama) harus selalu terbuka untuk diperdebatkan. Pada tahap yang paling ekstrem, mereka yang terjangkit skeptisisme akut akan meragukan tidak hanya kebenaran posisinya sendiri dengan berkata "I don't know" (nescio) bahkan juga mengklaim bahwa kebenaran hanya bisa dicari atau didekati, tetapi mustahil ditemukan (nesciam). Dalam literatur filsafat Yunani Kuno, sikap mental semacam ini dinamakan arrepsia (bimbang, sangsi) dan aoristia (bingung, tidak bisa memutuskan).

Gejala kedua adalah berpaham relativistik. Pengidap relativisme epistemologis menganggap semua orang dan golongan sama-sama benar. Semua pendapat (agama, aliran, sekte, kelompok dan sebagainya) sama benar bergantung pada sudut pandang masing-masing. Menurut paham ini, kebenaran berada dan tersebar dimana-mana, namun semuanya bersifat relatif. Anda, saya, ataupun dia, tiap-tiap individu sama-sama benar, tidak boleh menyalahkan satu sama lain, dan tidak berhak mengklaim diri sebagai yang paling benar. Jika seorang skeptis menolak semua klaim kebenaran, maka seorang relativis menerima dan menganggap semuanya benar (panaletheisme). Dalam hal ini, relativisme epistemologis adalah identik kalau bukan sinonim dengan pluralisme. Jika diteliti dengan seksama, paham seperti ini sebenarnya bangkrut. Darimana ia dapat menyimpulkan, bahwa semua pendapat adalah benar? Padahal, konsep "benar" itu ada justru karena adanya konsep "salah".

Gejala lain yang ditunjukkan oleh pengidap kanker epistemologis adalah kekacauan akal (intellectual confusion). la tidak lagi bisa membedakan yang benar dan yang salah, yang haq dan bathil. la cenderung menyamakan dan mencampuradukkan keduanya. Garis demarkasi yang memisahkan kebenaran dan kepalsuan tidak mampu dilihatnya. Hal yang paling parah jika hal ini menyebabkan si pasien lantas menganggap kebenaran sebagai kebatilan dan sebaliknya meyakini kebatilan sebagai kebenaran. Seperti mereka yang termakan tipu muslihat Dajjal, melihat air sebagai api, dan api sebagai air.(Syamsuddin Arif, tanpa tahun, xiii-xiv).

Sesuai dengan apa yang saya diskusikan sebelumnya, bisa jadi sebagian dari kita sudah terkena (mungkin tanpa sadar) penyakit kanker epistemologis tipe kedua yakni berpaham relativistik. Tanpa sadar kita menganut pemahaman ini untuk mencari kebenaran yang mungkin kebenaran tersebut tidak mendekati dirinya bahkan bisa jadi menjauh darinya. Identik dengan pernyataan seorang 
filsuf bahwa "kita hanya mampu mendekati kebenaran namun mustahil untuk menemukannya. Hal ini dapat dianalogikan dengan seseorang yang tersesat di tengah hutan dan berusaha mencari jalan keluar (baca: kebenaran), namun setelah berusaha beberapa lama ternyata ia hanya berputar-putar di hutan tanpa mampu menemukan jalan keluarnya. Boleh jadi ia akan terus berusaha mencari jalan keluar (kebenaran) itu sampai ajal menjemputnya atau ia akan berputus asa dan selamanya terpenjara dalam kebingungan. Saya jadi bertanya "apakah memang manusia ditakdirkan untuk hidup dalam kebingungan dan tidak tahu arah dalam menjalani kehidupan ini?" Apakah manusia tidak diberi kemampuan untuk mencari kebenaran yang sesungguhnya?

Marilah kita sejenak merenungkan anugerah Tuhan yang diberikan kepada kita sebagai modal untuk mencari kebenaran. Potensi itu adalah akal. Saya mencoba membahas potensi akal ini dalam sudut pandang Islamic values. Akal bagi manusia merupakan bagian yang sangat esensial yang membedakannya dengan makhluk ciptaan Allah yang lain, sehingga Allah menempatkan manusia sebagai ciptaan-Nya dalam bentuk yang sebaik-baiknya (QS. At Tiin: 4). Dengan akal manusia mampu mengembangkan ilmu pengetahuan dan peradabannya menjadi lebih mulia. Walapun di sisi yang lain, akal pula lah yang membuat manusia bisa menjadi lebih hina dibandingkan seekor binatang. Sebagaimana firman Allah : Atau apakah kamu mengira bahwa kebanyakan mereka itu mendengar atau memahami. Mereka itu tidak lain, hanyalah seperti binatang ternak, bahkan mereka lebih sesat jalannya/dari binatang ternak itu, (QS. Al Furqaan: 44). Patut disadari betapa pentingnya akal bagi kehidupan dan kesejahteraan manusia sehingga diperlukan kehati-hatian dalam menjalankan fungsinya dalam menghasilkan pemikiran-pemikiran yang sejalan dengan hakikat (fitrah) manusia itu sendiri. Jika alatnya (baca:akal) digunakan secara benar maka produk yang dihasilkannya (baca:hasil berpikir/pikiran) juga akan benar (Sulistiyo, 2011a).

Secara faktual, akal melekat dalam diri manusia. Hal ini menegaskan bahwa akal bukanlah suatu wujud yang berdiri sendiri, sebagaimana otak yang ada dalam kepala manusia. Oleh karenanya seseorang yang berotak belum tentu berakal. Hal ini kita pahami terjadi pada orang yang gila atau tidak waras. Pada konteks inilah hukum Islam (syariat) hanya diberlakukan pada seseorang yang sudah sempurna akalnya (QS. Al Furqaan: 44). Dengan kesempurnaan akal inilah tidak ada alasan bagi manusia untuk tidak menggunakannya dalam rangka 
memahami dan memikirkan ayat-ayat Allah. Bahkan jika tidak melakukannya maka Allah akan murka kepada manusia yang lalai menggunakan akalnya (QS. Yunus: 100). Beberapa ayat dalam firman Allah berikut menggambarkan bagaimana manusia diperintahkan untuk menggunakan akalnya:

Apakah kamu tidak memperhatikan, bahwa sesungguhnya Allah menurunkan air dari langit, maka diaturnya menjadi sumber-sumber air di bumi kemudian ditumbuhkan-Nya dengan air itu tanam-tanaman yang bermacammacam warnanya, lalu menjadi kering lalu kamu melihatnya kekuning-kuningan, kemudian dijadikan-Nya hancur berderai-derai. Sesungguhnya pada yang demikian itu benar-benar terdapat pelajaran bagi orang-orang yang mempunyai akal. (QS Az Zumar [39] : 21). Sesungguhnya pada kisah-kisah mereka itu terdapat pengajaran bagi orang-orang yang mempunyai akal. Al Quran itu bukanlah cerita yang dibuat-buat, akan tetapi membenarkan (kitab-kitab) yang sebelumnya dan menjelaskan segala sesuatu, dan sebagai petunjuk dan rahmat bagi kaum yang beriman. (QS Yusuf [12] : 111). Allah menyediakan bagi mereka azab yang keras, maka bertakwalah kepada Allah hai orang-orang yang mempunyai akal; (yaitu) orang-orang yang beriman. Sesungguhnya Allah telah menurunkan peringatan kepadamu. (QS Ath Thalaaq [65] : 10).

Penting untuk digarisbawahi mengenai penekanan bahwa orang yang berakal adalah juga orang yang beriman kepada Allah. Al Quran sebagai kitab Allah dan petunjuk bagi manusia berisi banyak hikmah dan pelajaran. Dengan memahami kandungan Al Quran tersebut akan membimbing seseorang kepada keimanan yang hakiki. Tentu saja orang yang dapat mengambil hikmah dan pelajaran yang terkandung dalam Al Quran haruslah orang yang berakal (QS. Ar R'ad: 19).

Dalam berpikir seorang manusia dihadapkan pada kenyataan bagaimana menentukan sebuah kebenaran pada setiap realitas kehidupan yang dialaminya. Upaya untuk menentukan benar dan salah inilah yang menuntut manusia menggunakan logikanya dalam berpikir. Sebenarnya berpikir dengan logika merupakan salah satu alat yang dapat digunakan manusia untuk mengkaji sebuah kebenaran yang tampak dari suatu realitas. Artinya kebenaran suatu realitas baik yang nampak (visible) maupun yang tidak nampak (invisible) yang terbentang di alam semesta ini tidaklah semata-mata ditentukan oleh akal manusia, (QS. Al A'raaf: 179). Namun demikian kebenaran logika dalam berpikir sangatlah membantu manusia untuk memecahkan berbagai permasalahan hidup 
yang dihadapinya sebagai salah satu upaya mencari kebenaran yang sesungguhnya.

Dalam konteks ini memang manusia dianugerahi Allah berupa akal yang membedakannya dengan makhluk lain. Perbedaan ini mengandung maksud bahwa manusia diberikan akal untuk digunakan sebagai bekal dalam mengarungi bahtera kehidupan yang selalu sarat dengan berbagai masalah dan problematika yang harus dipecahkan. Salah satu kunci untuk memecahkan masalah tersebut dengan jalan mengembangkan ilmu pengetahuan. Perlu disadari bahwa pengembangan ilmu pengetahuan tidak bisa dilepaskan dari peran serta akal manusia walaupun ada beberapa pandangan yang berbeda tentang hal ini. IImu manusia adalah hasil dari kerja akal yang dilakukan oleh manusia dalam rangka membentuk pengetahuan, pemahaman, pola pikir (tashawwur) dan ilmunya tentang sesuatu yang mengelilinginya, jadi akal ini meliputi memahami, mengingat, membedakan antara sesuatu yang ada, menganalisis, membandingkan, menyimpulkan, memutuskan, dan merenungkan, (Supriyatno: 2011:125).

Dunia tidak lain adalah subyektifitas yang disepakati, dunia adalah persepsi kita yang juga dialami orang lain.

(Faz 2007, 44)

\section{Memandang Realitas Dalam Kacamata Relativitas Kebenaran}

Saya teringat sebuah contoh menarik yang berusaha membuktikan kebenaran dari konsep relativitas kebenaran. Walaupun kalau kita cermati bersama ketika para penganut relativitas kebenaran mengklaim bahwa konsepnya adalah benar maka tanpa ia sadari sudah terjebak pada upaya memutlakan (mengabsolutkan) konsepnya tersebut. Secara tidak langsung pula mereka menegaskan bahwa konsep relativitas kebenarannya lah yang mutlak benar sedangkan di luar itu mutlak salah. Lalu dimanakah relativitasnya ? sebuah konsep yang ambivalen...mana-mana jo.

Contoh yang saya maksud adalah cerita tentang kamera pengintai. Digambarkan ada empat buah kamera pengintai yang dipasang di empat penjuru mata angin yakni Utara, Selatan, Timur dan Barat. Lalu ada seseorang yang berjalan dari titik tengah dan bergerak maju ke Selatan. Kemudian kita melihat 
pergerakan orang tersebut dari posisi masing-masing kamera pengintai. Jika dilihat dari kamera sebelah Utara maka orang itu dianggap bergerak "menjauh" dari tempat awal ia berdiri. Dari sebelah Selatan maka kamera melihat orang itu bergerak "mendekat" pada dirinya. Bagi kamera pengintai di sebelah Barat maka orang tersebut bergerak ke "sebelah kanan" sedangkan bagi kamera di sebelah Timur maka orang itu bergerak ke "sebelah kiri". Seandainya ada orang lain yang ditanya sebenarnya orang yang tertangkap oleh empat kamera pengintai tersebut bergerak kemana? Besar kemungkinan tanpa ragu orang yang ditanya itu akan menjawab "tergantung dari sudut mana anda memandang". Jawaban "tergantung dari sudut mana anda memandang" dijadikan sebagai justifikasi atau pembenaran bahwa dalam semua hal kita memiliki kebenaran masing-masing. Memperkuat apa yang diklaim sebagai relativitas kebenaran.

Saya mencoba memberikan perspektif berbeda atas contoh kamera pengintai tersebut. Saya berpikir bahwa perbedaan dalam menentukan posisi dari orang yang tertangkap kamera bukanlah mencerminkan perbedaan dalam kebenaran karena semuanya tidak perlu untuk diperdebatkan. Hal ini merupakan perkara yang sifatnya relatif namun bukan perihal kebenaran yang relatif. Jadi mesti kita pisahkan dengan tegas antara "perkara yang relatif" dan "kebenaran yang relatif".

Ada tesis lain yang dapat saya berikan untuk memperkuat pendapat tersebut. Saya membangun sebuah tesis dan anti tesis atas cerita kamera pengintai tesebut. Berikut penjelasannya :

$\checkmark$ Tesis : Setiap orang dapat menentukan dengan pasti di mana posisi sesungguhnya orang yang tertangkap kamera pengintai.

$\checkmark$ Antitesis : Setiap orang tidak dapat menentukan dengan pasti di mana posisi sesungguhnya orang yang tertangkap kamera pengintai.

Dapatkah kita menentukan mana yang benar dan salah dari dua pernyataan sebelumnya? Membandingkan dengan kenyataan yang ada maka daya nalar kita yang jernih akan memutuskan bahwa pernyataan tesis lah yang "salah" dan pernyataan antitesis lah yang "benar". Apakah kita akan mengatakan bahwa pernyataan tesis juga "benar relatif" ? Saya yakin tentu tidak karena nampak jelas bahwa yang benar itu benar dan salah itu juga salah.

Menentukan dengan pasti atau menggambarkan dengan tepat dimana posisi seseorang tentu tidaklah mungkin dan mustahil dilakukan oleh siapapun. Manusia memiliki keterbatasan panca indera untuk menangkap dan mengamati 
fenomena. Oleh karena itu saya ingin menegaskan bahwa apa yang selama ini kita anggap dalam wilayah diskusi kebenaran relatif, sebenarnya merupakan perkara yang sifatnya relatif sehingga tidak perlu ada perdebatan di dalamnya. Hal ini sekaligus juga mengkritik upaya membawa perkara yang relatif dipakai sebagai dasar untuk menjustifikasi adanya relativitas kebenaran dalam semua hal.

\section{Diskursus Akuntansi Dalam Wacana Relativitas Kebenaran}

Dalam sebuah sesi kuliah, sang guru bijak mendiskusikan sesuatu yang mengganjal tentang apa itu akuntansi. Kami ditanya satu per satu mengenai pandangan kami. Diantara kami ada yang menyampaikan bahwa akuntansi merupakan sebuah proses mekanistik dari pencatatan sampai dengan penyajian laporan keuangan, kemudian dinyatakan pula bahwa akuntansi sebagai "seni" mencatat transaksi atau pendapat lain memandang akuntansi sebagai media pertanggungjawaban aktifitas keuangan maupun non keuangan seorang agent kepada principal-nya. Masih banyak argumen lain yang dikemukakan, sejalan dengan sudut pandang kami masing-masing. Kembali sang guru bijak menegaskan adanya relativitas kebenaran dalam pendapat kami karena perbedaan pandangan mengenai akuntansi dan tidak ada kesamaaan satu sama lain. Mengharapkan adanya satu jawaban dari berbagai pikiran orang dalam satu hal yang sama tentu kecil kemungkinannya walaupun tidak dikatakan mustahil. Sekali lagi different eyes has different perspective menjustifikasi pernyataan tersebut. Saya tidak berupaya "mendobrak" aksioma ini karena bagi saya melanggar fitrah manusia itu sendiri. Sejenak mari kita melihat dengan perspektif yang lain atas masalah akuntansi tersebut.

Menurut saya sepanjang kita masih berbicara tentang bagian-bagian dari "sosok akuntansi" maka sebenarnya kita sedang berusaha untuk mengkonstruksi secara lebih utuh apa yang kita sebut sebagai "sosok akuntansi" tersebut. Sosok akuntansi bisa saja terdiri atas proses mencatat, seni mencatat atau bentuk pertanggungjawaban. Sama halnya ketika kita menggambarkan sosok seekor kucing yang memiliki bulu, kumis, ekor, dan berkaki empat. Ketika kita menggambarkan akuntansi dengan sebuah proses mencatat...dst, barangkali kita sedang menggambarkan "bulu" dari sosok akuntansi. Seni mencatat dapat dianggap sebagai "kumisnya" sosok akuntansi. Begitu pula dengan bentuk 
pertanggungjawaban dapat kita analogikan dengan menggambarkan "ekornya" akuntansi. Dalam konteks ini semua jawaban atau pendapat tentang sosok akuntansi maupun sosok seekor kucing dapat dibenarkan (bukan relatif tentunya) karena semuanya berupaya untuk menggambarkan bagian-bagian dari kebenaran realitas itu sendiri. Apakah kita mungkin menemukan kesalahan dalam mendeskripsikan kedua sosok tersebut?

Jawabannya mungkin sekali. Kemungkinan inilah yang sekali lagi menggugurkan asumsi adanya relativitas kebenaran. Seandainya saya mengatakan bahwa kucing itu memiliki dua buah sayap yang dapat membuatnya terbang, apakah pernyataan saya ini benar atau salah? Dengan daya nalar yang jernih tentu secara obyektif kita menilai bahwa hal itu adalah pernyataan yang salah (bukan benar relatif to??). Seandainya pula saya mengklaim bahwa akuntansi adalah ilmu untuk mengobati penyakit kanker stadium empat, sekali lagi apakah pernyataan saya ini salah atau benar? apakah pernyataan itu merupakan bagian dari penggambaran "sosok akuntansi" secara lebih utuh? Tentu tidak bukan.

Pemurnian kembali landasan berpikir kita tentang konsep kebenaran menjadi penting untuk dilakukan. Pemahaman relativitas kebenaran yang terlanjur melekat dalam pikiran dan mendoktrinasi semua proses berpikir kita dikhawatirkan semakin menjauhkan upaya mencari kebenaran dalam semua aspek kehidupan yang kita jalani. Saya teringat sebuah eksperimen menarik tentang seekor belalang. Ada temuan menarik dari sebuah lembaga penelitian di Toronto, Kanada berkaitan dengan uji coba terhadap dua ekor belalang peloncat. Singkatnya mereka menguji kedua belalang itu dalam tabung kaca yang berisi air. Air diisi hanya separuhnya. Kemudian diperhatikanlah aktifitas kedua belalang itu yang tampak meloncat-loncat ingin keluar dari tabung kaca. Setelah berkali-kali mencoba dan tidak berhasil maka kedua belalang tersebut akhirnya berhenti meloncat. Selanjutnya oleh para peneliti dibukalah penutup tabung kaca tersebut dan ingin melihat bagaimana kedua belalang itu bereaksi. Namun anehnya, tidak ada satupun upaya dari kedua belalang untuk keluar meloncat dari tabung kaca yang sudah terbuka. Hingga akhirnya keduanya terus diam dan kemudian mati karena tenggelam. Riset ini menunjukkan pada kita bahwa 
kebiasaan $^{1}$ yang kita lakukan merupakan proses berpikir yang dikerjakan secara berulang-ulang (Elfiky 2010, 91-92). Temuan riset tersebut tentunya menginspirasi kita semua bahwa kebiasaan berpikir akan mempengaruhi sikap dan perilaku yang akan dipraktekkan.

\section{Membangun Kebenaran Tentatif dalam Sebuah Proses Berpikir}

Seringkali tanpa sadar kita memisahkan antara kebenaran absolut sebagai milik Tuhan sehingga agama dan aliran kepercayaan ada dalam komunitas ini sedangkan kebenaran relatif ada pada ranah sains dan ilmu pengetahuan. Oleh karena itu sangat wajar jika dipahami kebenaran ilmiah cenderung bersifat relatif. Jika kita perhatikan dikotomis kebenaran ini justru kita melanggengkan cara berpikir "sekuler" karena kita menilai bahwa agama adalah kekuasaan Tuhan sehingga memiliki otoritas mutlak sedangkan sains dan ilmu pengetahuan adalah hak milik manusia sehingga kuasa relatif yang menjadi tuannya.

Perlu dipahami doktrinasi relativitas kebenaran mendorong munculnya egoisme dalam diri kita untuk berupaya secara sungguh-sungguh dalam mencari konsep kebenaran. Jika ada dua orang, sebut saja A dan B. Si A memiliki pendapat abc sedangkan Si B memiliki pendapat xyz. Dua orang tersebut berpaham relativistik sehingga masing-masing menganggap dirinya benar dan yang lainnya juga benar. Kalau memang Si A menganggap pendapat si $B$ juga benar, mengapa tidak ada keinginan dari Si A untuk mengganti pendapatnya sehingga sama dengan pendapat Si $B$ (dari abc berubah menjadi xyz). Boleh jadi Si A tidak mengubah tetapi mengelaborasi pendapat Si B menjadi abcxyz, mengapa hal ini tidak dilakukan juga? Dengan kata lain, mengapa Si A tetap mempertahankan pendapatnya sebagai yang paling benar? Artinya secara tidak langsung dan tanpa sadar $\mathrm{Si}$ A sudah mengklaim sifat absolut dalam pendapatnya, dan tidak relatif lagi bukan? Bukankah ini bentuk egosime dalam berpikir?

Dengan demikian apakah konsep absolutivitas kebenaran sebagai cara berpikir kita? Saya lebih menyukai untuk tidak terjebak dalam pemikiran absolutisme dan relativisme dalam memandang sebuah kebenaran. Bagi saya kebenaran tidaklah mengenal "sekutu", yang artinya benar dan salah seharusnya

\footnotetext{
${ }^{1}$ Kebiasaan diyakini sebagai pikiran yang diciptakan seseorang dalam benaknya, kemudian dihubungkan dengan perasaan dan diulang-ulang hingga akal meyakininya sebagai bagian dari perilakunya (lihat Elfiky 2010, h. 90)
} 
tampak jelas perbedaannya. Kalau memang kita menyadari sulit membedakan mana yang benar dan salah, hal ini sebenarnya adalah sesuatu yang wajar karena manusia memiliki keterbatasan alat indera dan akal dalam menangkap semua fenomena. Namun yang perlu diyakni adalah kebenaran itu ada dan pada saatnya nanti kita akan mengenalnya dengan baik dan jelas. Singkatnya yang perlu dibangun adalah kesadaran berpikir adanya "kebenaran tentatif" (bersifat sementara) dalam proses pencarian sains dan ilmu pengetahuan termasuk disiplin akuntansi.

Sebagai contoh dapat dicermati perjalanan sejarah ilmu tata surya kita yang mengindikasikan adanya dinamika perubahan kebenaran ilmiah dari satu periode ke periode berikutnya. Pada periode abad pertengahan (masa kegelapan/dark ages) diyakini bahwa bumi adalah pusat tata surya (teori geosentris). Kemudian tampillah seorang Copernicus pada masa renaissance dengan teori heliosentrisnya yang mendobrak pemahaman dogmatis kaum gereja tersebut dengan menyatakan kalau matahari adalah pusat tata surya kita. Di abad ini konsep tata surya sudah jauh berkembang karena ternyata alam semesta ini sangat luas dan terdiri atas ribuan galaksi dengan ratusan milyaran bintang dan tentu saja matahari hanya bagian yang sangat kecil darinya (Shahab, 2007).

Dalam pemikiran alam semesta yang sudah modern ini, tentunya klaim kebenaran teori geosentris maupun heliosentris sudah gugur dengan sendirinya. Kita tidak lagi mengatakan bahwa kedua teori tersebut memiliki kebenaran karena asumsi maupun realitasnya sudah terbantahkan dengan penemuan ilmiah modern. Dengan demikian nampak adanya sifat kesementaraan (tentatif) dari sebuah kebenaran ilmiah, yang sangat mungkin apa yang kita yakini sebagai sesuatu yang benar ilmiah pada saat ini maka di masa yang akan datang akan kembali digugurkan dan terbantahkan. Namun satu hal yang perlu ditegaskan bahwa alam semesta ini sudah terbentuk jauh sebelum manusia diciptakan sehingga kebenaran ilmiah tentang alam semesta itu sendiri sudah ada dan nyata, akan tetapi akal manusia maupun perangkat sains dan teknologinya belum mampu mengungkap kebenaran yang sesungguhnya.

Pada konteks akuntansi, dinamika kebenaran tentatif ini juga berlaku. Mulai era Pacioli sampai dengan tahun 1970-an kita hanya mengenal laporan keuangan yang berorientasi pada laba. Kemudian tulisan Tinker (1980) yang dipertegas oleh Cooper dan Sherer (1984) mengimplikasikan perlu adanya 
muatan nilai sosial, ekonomi dan politik dalam laporan akuntansi. Demikian pula ide yang dimunculkan oleh Mulawarman (2008) tentang laporan nilai tambah syariah maupun Sukoharsono (2010) mengenai akuntansi sustainabilitas berdimensi spiritualitas sama-sama berupaya untuk mengkonstruksi ulang laporan keuangan yang berorientasi semata pada laba dan kepentingan "borjuis" pemilik modal menjadi lebih bernuansa spiritual dan relijius.

Perkembangan pemikiran akuntansi mulai dari era 1970-an hingga saat ini dapat dianggap sebagai transformasi kebenaran yang bersifat tentatif. Baik Tinker, Cooper \& Sherer, Mulawarman maupun Sukoharsono sama-sama berupaya mengkonstruksi "sosok akuntansi" dalam bentuk yang lebih utuh dan mudah dikenali. Semakin banyak bagian-bagian akuntansi yang ditemukan, akan memudahkan dalam merajut 'sosok akuntansi" yang lebih baik. Tentu tidak pada tempatnya kalau kita memasukkan pemikiran Copernicus, Galileo Galilei, Newton atau Einstein sekalipun dalam membangun "sosok akuntansi" karena daya nalar kita yang jernih akan menyatakan hal ini sebagai upaya yang salah (baca:bukan benar relatif).

\section{Renungan Akhir}

Di akhir tulisan ini saya ingin menegaskan kembali bahwasanya konsep relativitas kebenaran tanpa kita sadari sudah menjadi "doxa" dan menghegemoni cara berpikir kita. Dengan klaim relativitasnya yang mengakui bahwa semua hal adalah benar menjadikan kita bagaikan orang buta yang berusaha mencari jalan keluar dari perangkap kegelapan. Kita tidak bisa lagi membedakan mana yang benar dan salah karena yang salah dianggap memiliki kebenarannya sendiri dan yang benar juga "dilarang" menganggap dirinya sebagai yang paling benar. Lagilagi sebuah konsep yang kabur, remang-remang dan ambivalen, padahal sebuah kebenaran lahir ketika sebuah kesalahan dapat dikenali dengan baik. Akuntansi sebagai bagian dari ilmu sosial tentunya memiliki kebenaran ilmiah yang bersifat tentatif. Tentatif bukanlah relatif. Tentatif tidaklah menafikan adanya kesalahan dalam pencarian sebuah ilmu pengetahuan, namun yang selalu ditekankan adalah semangat untuk terus dan tak kenal lelah dalam mencari kebenaran. Sebuah upaya yang berujung pada kebenaran dalam disiplin akuntansi. 
"Akan Aku palingkan mereka yang arogan di muka bumi tanpa kebenaran itu dari ayat-ayatKu. Sehingga, meskipun menyaksikan setiap ayat, tetap saja mereka tidak akan mempercayainya. Dan kalaupun melihat jalan kebenaran, mereka tidak akan mau menempuhnya. Namun jika melihat jalan kesesatan, mereka justru menelusurinya...(Al A'raaf: 146).

\section{DAFTAR PUSTAKA}

Arif, Syamsuddin. 2008. "Orientalis dan Diabolisme Pemikiran”. Cetakan I. Penerbit Gema Insani. Jakarta.

Chua, Wai Fong. 1986. "Radical Developments in Accounting Thought". The Accounting Review. The Accounting Review LXI 4: 601-32.

Cooper, David J. dan Sherer, Michael J. 1984. 'The Value of Corporate Accounting Reports: Arguments for A Political Economy of Accounting". Accounting, Organizations and Society. Vol. 9. pp. 207-232.

Elfiky, Ibrahim. 2010. "Terapi Berpikir Positif”. Terj. Penerbit Zaman. Jakarta.

Faz, Ahmad Thoha. 2007. "Titik Ba: Paradigma Revolusioner Dalam Kehidupan dan Pembelajaran”. Cetakan I. Penerbit Mizan. Bandung.

Gummesson, Evert. 2003. "All Research is Interpretive!". Journal of Business \& Industrial Marketing. Vol. 18. pp. 482-492.

Mujahid, Abu. 2011. "Pemuja Filsafat: Pengantar Untuk Tidak Menyukai Filsafat". Cetakan I. Penerbit Toobagus Publishing. Bandung.

Mulawarman, Aji D. 2008. "Eksistensi Laporan Nilai Tambah Syariah Berbasis Rezeki”. Prosiding Simposium Nasional Akuntansi XI. Pontianak.

Purwanto, Yadi. 2007. "Epistemologi Psikologi Islami Dialektika Pendahuluan Psikologi Barat dan Psikologi Islami". Penerbit PT Refika Aditama. Bandung.

Sarantakos, S. 1993. "Social Research". South Melbourne: Macmillan Education Australia Pty Ltd.

Shahab, Idrus. 2007. "Beragama dengan Akal Jernih". Cetakan I. Penerbit PT Serambi Ilmu Semesta. Jakarta.

Sukoharsono, Eko G. 2010. "Metamorfosis Akuntansi Sosial dan Lingkungan: Mengkonstruksi Akuntansi Sustainabilitas Berdimensi Spiritualitas". Pidato Pengukuhan Guru Besar FE Univ. Brawijaya. Desember. Dipublikasikan. 
Tinker, A.M. 1980. "A Political Economy of Accounting". Accounting, Organizations and Society. pp. 147-160.

Sulistiyo, Agung B. 2011a. "Akal Memikirkan Kebenaran ₹ Pikiran Mengakali Kebenaran". Paper Tidak Dipublikasikan. pp. 1-11.

Sulistiyo, Agung B. 2011b. "Antara Seni Berperang Ala Sun Tzu, Akuntansi dan Sustainabilitas Organisasi”. Paper Tidak Dipublikasikan. pp. 1-20.

Supriyatno, Triyo. 2011. "Epistemologi Pendidikan Ibn Qayyim al-Jawziyyah". Penerbit UIN-Maliki Press. Malang. 